\title{
Boostering Students’ Life Skill through IT Based Project Learning
}

\author{
Dewi Sri Wahyuni ${ }^{1}$, Hasan Zainnuri ${ }^{1}$ \\ ${ }^{1}$ English Education Department, Faculty of Teacher Training and Education, Universitas \\ Sebelas Maret. \\ Jalan Ir. Sutami No. 36 A, Kentingan, Surakarta, Central Java, Indonesia.
}

\begin{abstract}
The Indonesia Qualification Framework (IQF) implicitly states that institutions serving undergraduate program should prepare students with life skill through their curriculum development. In the undergraduate program curriculum, hard skills and soft skills have to be given accordingly; hence, life skills as the outcome are gained simultaneously. Due to the background above, this research is questioning how the mixing of Information and Technology (IT) as learning media and project based as learning method can booster the students' life skills. Conducting classroom action research is the right method to answer the question. Taking a class of Business English Writing in English Department Program of Teacher Training and Education Faculty of Universitas Sebelas Maret, this research was handled within the whole semester. The result shows that project based learning is best applied when it is combined with the use of IT and provided with the context of real world because students life skills have to meet the today world needs in which they have to be able to work with IT and develop entrepreneurship as part of life skills.
\end{abstract}

\section{Keywords: students' life skill; project based learning; IT learning media; real world context}

\section{INTRODUCTION}

As a growing nation, Indonesia puts physical and nonphysical developments accordingly to reach the goals that have been stated clearly in the National Constitutions. Both developments are nationally-wide conducted by all elements in the society. In physical development, there are facilities built to serve the development itself; such as school, factory, bridge, airport, etc. To illustrate the physical development, we can use "action verbs". Meanwhile, the nonphysical development is focused on the empowering human as the actor of development. Indonesian government projected many fields to empower human. One of the fields is education. Bridging the empowering human power and educational field, the government holds a Board of Indonesian Qualification Framework through Presidential Decree No.8 /2012. The Indonesian Qualifications Framework (IQF) is an instrument for levelling framework qualifications and competences of Indonesian man power. It compares balances and integrates education and training sectors, as well as job experiences, in a scheme of competence acknowledgement for specific occupational requirement. It also 
appropriately reveals the Indonesia man power quality and personality related to the outcomes of national education and training system, as well as job career development system in producing qualified and productive human resources. Due to the quality of diversity in education outputs from formal and informal institutions, the IQF plays its role as a sole reference for all education and training institutions to prepare human resources in filling job occupations or creating own job. The current employees can therefore be assessed to equate a suitable qualification level of the IQF. The IQF is expected to push education and training institutions, especially to those belonging higher education qualifications, to accelerate quality improvement for both national and international contexts. IQF is also seen to improve the quality of man power and national competitiveness in facing open global trade challenges. Obviously, the implications of IQF are (1) increasing the quality of Indonesia man power with high quality and internationally competitive capabilities that granting greater access into national and international job markets; (2) increasing the contribution of learning outcomes achieved through formal and informal education or job experiences into national economic growth; (3) increasing academic mobility for improving mutual understanding solidarity and collaboration between university across countries in the world; and (4) increasing other country's recognition of Indonesia both regionally and internationally without abandoning the national identity and personality (source : iqf_booklet_english: http://kkni-kemenristekdikti.org).

The IQF classifies education level for both formal and informal into 9 qualifications. Conceptually, every level of qualification is built upon some parameters, namely: science, knowledge, know-how, skill, affection, and competency. Those parameters are known as qualification descriptors. The qualification descriptors are arranged orderly within levels to explain competencies in field work, science and knowledge of field work with managerial skills which is termed out as learning outcomes. In short, learning outcomes is the process of internalization and accumulation of science, knowledge, skill, affection, and competency which are gained through educational system involving certain discipline or work experience. There are three aspects in learning outcomes, affective, science (knowledge), and skills (general and specific skills).

Based on the IQF levelling education, the undergraduate program is classified into level number 6. The descriptors of this level are (1) capable of applying science, technology and art within expertise and is adaptive to various situations faced during solving a problem; (2) mastering in-depth general and specific theoretical concepts of formulating related problem solving procedures; (3) capable of taking strategic decisions based on information and data analysis and provides direction in choosing several alternative solution; and (4) responsible for own job and can be assigned responsibility of the attainment of organization's performances (source : iqf_booklet_english: http://kkni-kemenristekdikti.org). These descriptors are formulized into learning outcomes.

Since the attention of learning outcomes is changing, today's education is not only focusing on the development of hard skills but also soft skills. The curriculum is now designed with the consideration of market, the graduation users or stakeholder. The discussion for designing curriculum moves from raising only literacy skills toward skills required by the workface to promote economic growth. This issue becomes crucial in higher education. Sharma (2003) noted that higher education experts say that universities are coming under increasing pressure to ensure that their graduates are 
'employable', although preparation for 'employability' is still only rarely incorporated in university courses, and the skills that could make a difference in finding employment and ways to deliver those skills are still not evident.

Considering today's requirement in education, English Education Department (EED) of Teacher Training and Education Faculty, Universitas Sebelas Maret develops its curriculum based on the IQF. The descriptors of English language teaching are framed into list of courses and hopefully, the excellent English language teacher as the outcome learning can be reached. Implicitly, the learning outcomes of EED can be recognized into soft skills and hard skills. Holmes, Bradford (2014) defines soft skill as the ability to adapt and changing circumstances and the willingness to learn through experience, and are applicable across multiple disciplines and careers. He also described five soft skills must have for university students. (1) Collaboration: It is imperative for college-bound students to function efficiently and appropriately in groups, collaborate on projects and accept constructive criticism when working with others. People who succeed only when working alone will struggle in college and beyond, as the majority of careers require collaboration. (2) Communication and interpersonal skills: A common complaint among employers is that young people do not know how to effectively carry on a conversation and are unable to do things like ask questions, listen actively and maintain eye contact. (3) Problem-solving: Students will be faced with a number of unexpected challenges in life and receive little or no aid in overcoming them. They must be able to solve problems in creative ways and to determine solutions to issues with no prescribed formula. Students who are accustomed to learned processes, and who cannot occasionally veer off-course, will struggle to handle unanticipated setbacks. Students can improve problem-solving abilities by enrolling in classes that use experiential learning rather than uncomfortable situations. (4) Time management: Whatever structure students may have had in high school to organize their work and complete assignments in a timely manner will be largely absent in college. It is imperative that they be fully self-sufficient in managing their time and prioritizing actions. (5) Leadership: While it is important to be able to function in a group, it is also important to demonstrate leadership skills when necessary. Both in college and within the workforce, the ability to assume the lead when the situation calls for it is a necessity for anyone who hopes to draw upon their knowledge and "hard" skills in a position of influence.

Holmes's concept on soft skills for university students is adopted by EED in defining its learning outcomes, especially in aspect of affective, by adding some religious affairs as the state's requirements and local wisdoms. Through affective aspect, graduate students of EED are expected to have religious attitude and in academic and non-academic life; stand for humanity; internalize value, norms, and etiquette in academic field; have commitments as good citizen; have empathy on diversities; have abilities in working in group, as leader or member, either in working field and community; and many more. Promoting soft skills above in process of learning cannot be separated from the process of teaching hard skills.

Meanwhile, the term hard skills refer to abilities and intelligence, and may include the area of specialization such as data analysis or the technical expertise. It is the knowledge of professional techniques or methods which help in carry out professional work with proficiency. The descriptors of level 6 defined by the IQF framing hard skills can be seen on the learning outcomes; specifically, the competencies on knowledge 
comprehension and skills. In EED, students are given hard skills on English language proficiency, knowledge on English as language, and English as language education.

Entwined soft skills and hard skills, students of EED are led to have life skills of English education. Cited from http://www.macmillanenglish.com/life-skills/why-arelife-skills- important/, the definition of life skills can be recognized as the skills we need to deal effectively with the challenges in everyday life, whether at school, at work or in our personal lives. Students who are able to understand and use these skills, along with their educational qualifications, will be better placed to take advantage of educational and employment opportunities. The importance of life skills is that the students are able to cope the increasing pace and dramatic change of modern life impacting on education, the workplace and home life. It cannot be denied that students need new life skills such as the ability to deal with stress and frustration. Today's students will have many new jobs over the course of their lives, with associated pressures and the need for flexibility. There are also some benefits of life skills for individual, employment, and society. In everyday life, the development of life skills helps students to find new ways of thinking and problem solving, recognize the impact of their actions and teaches them to take responsibility for what they do rather than blame others, build confidence both in spoken skills and for group collaboration and cooperation, analyse options, make decisions and understand why they make certain choices outside the classroom, and develop a greater sense of self- awareness and appreciation for others. The benefit in life skills in working life are the ability to self-manage, solve problems and understand the business environment, working well as part of a team, time and people management, agility and adaptability to different roles and flexible working environments, and the potential to lead by influence. The more students develop life skills individually, the more these affect and benefit the world: recognizing cultural awareness and citizenship makes international cooperation easier, respecting diversity allows creativity and imagination to flourish developing a more tolerant society , and developing negotiation skills, the ability to network and empathize can help to build resolutions rather than resentments. Having these life skills as learning outcomes, the graduations of EED are expected for applying the knowledge in the real world, handling problems which come out, and solving the problems in procedural track.

In EED curriculum, all of subjects are designed incorporating to the IQF descriptors. Both hard skills and soft skills are taught accordingly in order to prepare students facing real world with well-built life skills. One of the choice subjects offered is Business English, both in writing and conversation. The learning outcome of this subject is preparing students with life skills usually found in the international business world. The life skills gained in the end of the course period is the ability to self-manage, solve problems and understand the business environment, working well as part of a team, time and people management, agility and adaptability to different roles and flexible working environments, and the potential to lead by influence, recognize cultural awareness and citizenship makes international cooperation easier, respect diversity allows creativity and imagination to flourish developing a more tolerant society, and develop negotiation skills, the ability to network and empathize can help to build resolutions. Through years of observation, the researcher as the lecturer found that learning in Business English Writing (BEW) class, somehow, succeeds in giving students with hard skills (for example: how to correspond in business, compose business letters, make company profile, write application letter with resume) and soft skills (such as: ability to work in group, stand as leader, internalize value, norms, and 
etiquette in international business, communicate effectively, manage the time given, respect diversities, and so on). Unfortunately, the students' life skills were less from the expectation. The less life skills were revealed through personal communication (informal interview) with the graduated students. Some of students, when they were asked about writing application letter, found difficulties in choosing the correct diction. Some of the words, they said, did not reflect the today's vocabulary in business affairs. They also stated that they have less ability in corresponding with electronic media because they used to hold paper-based corresponding. They are not familiar doing business writing using social media or IT (Information and Technology) based corresponding. To sharpen the students' life skills on international business writing (for not being underestimate and able to handle works in the business writing affairs when they work in the international or national companies), it is necessary to find out the sources of the problem. Reviewing the syllabus of BEW (in order to make it applicable and meet the requirements of today business writing affairs), there were some aspects that had to be revised. They were the use of media in learning and the method of learning. The media were no longer paper-based corresponding but the IT based corresponding. The method of learning was also changed into project based learning. This research is then questioning on how can the mixing of IT as learning media and project based as learning method booster the students' life skills.

Generally, media in education can be concerted as everything that can be used to stimulate thoughts, feelings, concerns and abilities or skills of learners so as to facilitate the process of learning. Media is an ideal way of getting a message across. Media of teaching are vary. In printed media, there are books, journal, hand out, worksheet, etc. In electronic media, there are visual, audio, and audio visual. Each kind of media offers its own advantages and disadvantages while using in the classroom. The use of media is broader for these years; not only conventional media that can be used to deliver the material but also electronic media. Hand in hand with today digital growth, media finds its new face; that is information and technology (IT) based media. IT based media is type of electronic media used in teaching and learning process connected to internet. The most popular IT based media is social media. Social media includes varied online technology tools that allow people to communicate easily via the Internet to share information and resources. The dramatic growth of social media creates new opportunities for engaging students. These include social networking sites such as Facebook, Myspace, LinkedIn and Twitter along with blogs and wikis. Social media are rapidly changing the way we interact with one another. The advantages of using social media in the classroom are interaction using social media provides students with a sense of belonging and creates bonds between students and their peers, and between students and the instructor and Students likely have some prior familiarity with sites such as Facebook or Myspace, lowering the "learning-curve" associated with using a new technology.

Reviewing http://www.cord.org/contextual-learning-definition, project-based learning is a teaching and learning strategy that engages students in complex activities. It usually requires several steps and some duration-more than a couple of class days and up to a semester-and cooperative group learning. Projects may focus on the development of a product or performance, and they generally call upon students to organize their activities, conduct research, solve problems, and synthesize information. Projects are often interdisciplinary. For example, a project in which students draft plans for and build a structure, investigate its environmental impact, document the building 
process, and develop a budget would involve the use of skills and concepts drawn from courses in English, mathematics, construction trades, drafting and/or design, and biology. Although projects as a methodology are not a new concept; it is an approach that supports the many tasks facing teachers today such as meeting state standards, infusing higher-order thinking skills, guiding students in life choices, and providing experiences that tap individual student interests and abilities. Furthermore, the student products created during projects provide the means by which teachers can include authentic assessment in their instruction.

\section{METHOD OF THE RESEARCH}

To find out the answer of how can the mixing of IT as learning media and project based as learning method booster the students' life skills, the researcher conducted classroom action research. Action research is about systematic study of attempts to improve educational practice by groups of participants by means of their own practical action and by means of their own reflection upon the effects of those actions (Ebbut in Hopkins, 1985: 34). Similarly, Burns (1999: 30) said "The action research is the application of fact finding to practical problem solving in social situation with view to improve the quality of action with involving collaboration and cooperation of researchers, practitioners, and laymen". The statements imply that classroom action research is a specific and contextual research that is done to improve educational practice involving teacher, students, and other relevant practitioners of education. Action research is contextual, small-scale and localized-it identifies and investigates problems within a specific situation. This research adopted model designed by Kemmis and Taggart in Burns (1999: 32). The steps within the model are (1) Identifying problems, before planning the action, the researcher identified the problem by using observation that is used to know the student behavior in learning process, classroom management, and the quality of teaching and learning process and open-ended interview to the graduations for knowing how far the life skill given in BEW course can contribute to their work directly. (2) Planning, the researcher prepared lesson plan containing the material in doing international business writing which is IT based and project based as the method of learning. (3) Implementing the action, after preparing the instrument for the research, the researcher acted as the lecturer and helped by another colleague as collaborator in implementing the plan. (4) Observing or monitoring the action, the researcher observed the students' activity during learning process. This is done to know what happens, particularly, how the student's response is, when the plan is carried out. In this phase, the researcher was assisted by collaborator to observe all activities happening in the classroom. (5) Reflection, in this stage, the researcher analyzed data from the observation and made reflection from the result of analysis.

The data were analyzed using a systematic process of analysis and interpretation according to agreed criteria. After getting result from those series of actions and evaluations, the researcher then made a decision whether the technique implemented reaches the goal of improvement. If there is still no significant improvement or there are still many aspects needed correction or improvement, the next cycle will be implemented. (6) Revising the plan, the result of the reflection is used to revise the plan to next cycle. Based on the weakness of activity that has been carried out, the revised plan is needed when the action cycle does not make any betterment on students' life 
skills in learning BEW. The research was conducted in the class of Business English Writing for sixth semester within six months (a whole semester) from February to July 2016. The class consisted of 37 students.

In collecting the data, the researcher made use of (1) observation, observation is an activity to take regular and conscious notice of classroom actions and occurrences which are particularly relevant to the issue or topics being investigated (Burns, 1999: 80) and (2) interview, it is face to face personal interactions which generate data about the research issue and allow specific issues to be discussed from other people's perspectives (Burns, 1999: 117). Analyzing the data is carried out after the data taken. In analyzing qualitative data, the researcher uses constant comparative techniques as proposed by Burns (1999: 156), the steps are assembling the data, coding the data, comparing the data, building interpretations, and reporting the outcomes.

\section{RESULT AND DISCUSSION}

Before conducting the action, the researcher revised the syllabus of BEW and adjusted with the descriptors for level 6 as the requirement of the IQF. From the descriptors, there are learning outcomes arranged for all English education departments in Indonesia. The learning outcomes for BEW subject are mainly divided into three aspects. The first aspect is affective which can be included as soft skills. After joining BEW class, the students, hopefully, have some senses of human kind responsibility; such as: keep on faith of religious affairs; internalize value, norm, and academic ethical; responsible and loyal to the nation; respect diversities in culture, vision, religion, faith, and other opinion or finding; contribute in elevating life quality within society and nation; ability to work as a team or leader within a group; follow the rules stated by the government; develop entrepreneurship; willing to reach defined goals; and commit to maintain local wisdom for development in all aspects of life. The second aspect is knowledge in business English writing (included as hard skills). Mostly, the knowledge involved are knowledge on writing business letters, composing company profile, and making application letter with resume. The students, hopefully, comprehend the concept on English language and master the technique of communication either oral or written forms aimed to specific purposes (in this case is aimed at international business English affairs which are done in written form). The last aspect is skills, both specific and general skills. These skills included also as hard skills. In specific skills, students have to show the abilities in doing English communication written and orally for specific purpose (in business English writing), adapting positive culture of targeted language to mother language culture, and using relevant information communication and technology to develop quality of education. In general skills, students are able to analyze the implication of knowledge, technology in business English writing based on academic norm, value, etiquette for solving problems; to take decision effectively in business English writing based on information and data collected; and to develop and maintain networking with colleague, consultant, peer either from inside or outside the institutions.

After reviewed the syllabus of BEW and revised the learning outcomes, the researcher designed lesson plan for teaching the class. In the lesson plan, the learning outcomes were broken down into three basic competencies. The first is students have to master the knowledge on business English corresponding and apply the knowledge into 
real corresponding in the form electronic mails. The second is the students have to master the knowledge of application letter and resume and able to search job vacancies offered in the social media; in the end, they have to apply for the job with resume and application letter. The third is the students have to master the knowledge of composing company profile and make it into printed material and upload it into websites. The researcher, then, designed learning activities to cope those basic competencies with elaborating IT based media and project based learning. In teaching the first basic competency, the researcher asked the students to bring laptop to seek for types of business letters in the internet. Fortunately, the Faculty had prepared all building with internet line, so the students can access the internet in free. The class was grouped into 9 small groups with 4 until 5 members in each. Each group was assigned to seek different type of English business letters. The group A, for example, had to find out what inquiry letter is and how to write the letter. The group needed to download examples of inquiry letters from the internet, analyzed the letters (including diction, introduction, body, and closing), and resulted a template for writing inquiry letter. In the next meeting, each group had to present the result of discussion in from of the class. In the second basic competence, the lecturer asked the students to work in pair. Each pair had to search job how to write application letter and resume in the internet. Same as the first project of the former basic competence, the students should make up the template of application letter and resume. Only sample students asked to present their work in front of the class. The next project was that the students had to search job vacancies (in the internet) in which they had to meet the requirement listed in the vacancies. They had to send the application letter with resume via email. The project for the third basic competence was students had to make company profile designed for websites and booklet versions in small group. The groups needed to define in what service or product they want to perform. Some groups had their own real business, so it will be easier for them to design company profile. They knew the business very well. The groups had to consult on what things they write with the lecturer, including diction, grammar, outline, and design. The company profile should communicative, concise, straight, and eye-catching in the performance. This project was fully supported by IT based media.

This research was not planned for cycles because the functions of life skills improvement, in fact, can be seen thoroughly when the life skills will be used in the work days. The researcher, however, defined the criteria whether the combination of IT based media and project based learning was able to booster students' life skill in BEW through the improvement symptoms shown out by the students.

From the empirical data taken using observation method, it can be seen that there was a new atmosphere in learning business English writing. The class was not fully loaded with knowledge from the books but mostly knowledge on how to correspond in international business and compose company profile were adopted from the internet. The students searched their own material and it had to be consulted before presented in front of the class. The lecturer was no longer functioning as the main source of knowledge but as the facilitator of learning. The students were active in the process of learning and responsible for the assigned project. They could manage themselves for working within a group; otherwise, some of them rolled as leader in group. They also were able to manage time when they had to present the material. Activeness, responsibility, working as leader or member in group (cooperating), managing time are parts of soft skills stated in the affective learning outcomes of BEW. When the lecturer asked about what the students feel in joining the new face of BEW class, they stated 
that they needed to work hard during the semester but the class was awesome. They were excited with the project given. Doing the task with cheeriness and without complaining is the indicator of excitement. Moreover, the students were interested in the final project and highly motivated when they worked in group to do the project. They said that doing learning activity (in this case was designing company profile) was different amazing learning because they used to learn English education. For the first time, they learned English not as language in educational field but as language in business affairs. It opened their mind for having entrepreneurship. They learnt that in doing business must be started from the small thing: promoting their business. The most effective way in promoting business is using internet as the media. Because they had to upload their company profile in the websites or blogs, they needed to learn how to upload content in the websites or blog. The ability for making (including designing) their own websites and blogs is one of the hard skills stated in the learning outcomes of $\mathrm{BEW}$, besides the ability to write company profile. In designing websites or blogs, they had to show their sense of art because the websites and blogs must be eye-catching enough to make viewers interested in the content. The improvement in both soft skills and hard skills was the symptom shown by the students that their life skills also improve. It can be stated that when the soft skills and hard skills improve, the hard skills will also improve (although it only can be seen thoroughly when students graduate and work in some places).

The method of project based learning can be applied to booster students' life skills in BEW class due to some facts. The first is project based learning promotes REACT. It stands for Relating, Experiencing, Applying, Cooperating, and Transferring. In relating, the syllabus of BEW that attempts to place learning in the context of life experiences must, first, call the student's attention to everyday sights, events, and conditions. It must then relate those everyday situations to new information to be absorbed or a problem to be solved. The materials of BEW offer daily life context such as the use of media social in corresponding and defining business of their own. Students familiarize with browsing, uploading, posting, and other terms relating to internet. They know what and how to use. The project given in BEW is posting company profile on certain business using blog or website in group. The students in the group were able to handle and finish the project because they related their daily life (what things around that can be made up into business), the knowledge of using IT based media and writing business skills into well-designed of company business profile offering product or service. In experiencing, students learn to manipulate materials (business English corresponding) and media (IT based) for doing the projects (defining template for business letters, application, and resume) with exploring, investigating, and discovering (the examples of business English corresponding from the internet). In applying, students were projected into an imagined future (a possible career) or into an unfamiliar location (a workplace). The imagined future built in BEW class is as an entrepreneur for services or products business. It will give new sight for students that although English teacher is the main choice, they can have another way to earn money (doing entrepreneur). In cooperating, students need for sharing, responding, and communicating with other learners. These activities prepare life skills for students because employers espouse that employees who can communicate effectively, who share information freely, and who can work comfortably in a team setting are highly valued in the workplace. The projects in BEW class had to finish in group or team work, in which they had to role as leader or member actively. In transferring, students use and build upon what the student already knows. 
The students had known on writing skills; they need to transfer their knowledge in other form media; that is IT based media, rather than paper based media.

\section{CONCLUSION}

To booster students' life skills, a motivational and contextual method of learning (that is project based learning) and a modern and contextual learning media (that is IT based media) are required and entwined each another in contextual cooperative way. This combination will guide students in life choices, and providing experiences that tap individual student interests and abilities. Furthermore, the student products created during projects provide the means by which teachers can include authentic assessment in their instruction.

\section{REFERENCES}

[1] Brown, D. H. 2001. Teaching by Principle: An Interactive Approach to Language Pedagogy. New York: Longman.

[2] Huitt, W. (2011). Motivation to learn: An overview. Educational Psychology Interactive. Valdosta, GA: Valdosta State University. Retrieved from http://www.edpsycinteractive.org/topics/ motivation/motivate.html

[3] Rohmad, Zaini and Sri Wahyuni, Dewi. 2015. Community Service Learning: Bridging Contextual Learning Students’ Soft Skills Enhancement. Proceeding: AECON 2015. Purwokerto: UMP

[4] iqf_booklet_english: http://kkni-kemenristekdikti.org

[5] http://www.macmillanenglish.com/life-skills/why-are-life-skills-important/

[6] http://www.cord.org/contextual-learning-definition 